\title{
Jurnal
}

Manajemen Kesehatan Indonesia

Volume 8

Nomor 2

Agustus 2020

\section{Pengaruh Pengetahuan, Sikap, dan Perilaku Bidan dalam Pemanfaatan Buku KIA Selama Periode Antenatal terhadap Deteksi Dini Ibu Hamil Berisiko Tinggi (Studi Kasus di Kecamatan Solokan Jeruk dan Paseh Kabupaten Bandung)}

\author{
Nely Bonita*, Nanan Sekarwana**, Dinan S. Bratakoesoemo** \\ *Program Studi Magister Kebidanan, Universitas Padjadjaran Bandung \\ ** Staf Pengajar Program Studi Magister Kebidanan, Universitas Padjadjaran Bandung \\ Email:nelybonita93@gmail.com
}

\begin{abstract}
The MCH book is a book that contains maternal (pregnant, childbirth, postpartum) and child health records (neonates, infants, toddlers) which are used as a tool to reduce the number of mothers and babies. As one of the implementing officers, his role in the application of the MCH handbook was very large. Therefore, midwives must have knowledge, attitudes and thoughts about the endorsement of the MCH book so that they can be protected early. This study discusses the knowledge, attitudes and behaviour of midwives in the use of the MCH handbook during the antenatal period for early detection of high-risk pregnant women. This research was an analytic study using a cross sectional study design. A total of 44 midwives were taken using a total sampling technique. The type of primary data source uses a questionnaire that was adapted from the book evaluation instrument for health workers after the publication of the $\mathrm{MCH}$ book at the place of service from the Ministry of Health of the Republic of Indonesia and the Guidelines for Integrated Antenatal Services. The results showed that $47.7 \%$ were invited> 39 years, $65.9 \%$ worked $>9$ years, $84.1 \%$ had
\end{abstract}

attended training. Bivariate analysis with Chi Square test known variables associated with early detection are knowledge $(p=0.042)$, attitudes $(p=$ 0.018), and behaviour ( $p=0.008)$. Multivariate analysis with multiple logistic regression tests showed attitudes ( $p=$ $0.031)$ and behaviour $(p=0.008)$ affecting early detection, while knowledge ( $p=$ 0.070) was not required for early detection. There is a joint effect of knowledge, attitude and protection of midwives in the use of the MCH handbook on early detection of high-risk pregnant women with a significance value of 0.001 and $R^{2}$ of 0.435 , meaning that $43.5 \%$ of the early detection variables can be supported by variations of these variables. It can be concluded that attitude and behavior are dominant variables that oppose early detection of high-risk pregnant women.

Keywords: Knowledge, Attitude, Behavior, MCH Book, Early Detection of Risky Pregnant Women,

\section{PENDAHULUAN}

Paradigma pelayanan kebidanan saat ini telah mengalami perubahan yang awalnya hanya menunggu terjadinya 
komplikasi menjadi melakukan pencegahan komplikasi. Pencegahan komplikasi ini tentunya tidak akan berjalan dengan baik jika tidak dibarengi dengan menyiapkan peran ibu dan keluarga dalam menghadapi proses yang terjadi sepanjang siklus kehidupan wanita (continum care of life woman cycle). ${ }^{1}$ Salah satu upaya yang perlu dilakukan untuk menyiapkan peran tersebut yaitu dengan pemanfaatan buku KIA.

Buku KIA adalah penggabungan dari sejumlah kartu menuju sehat (KMS) dan Kartu Ibu Hamil yang berisi informasi dan materi penyuluhan tentang gizi dan kesehatan ibu dan anak, diberikan pada ibu saat pertama kali memeriksakan kehamilannya dan selanjutnya buku tersebut dibawa ibu untuk disimpan di rumah. Petugas kesehatan mencatat setiap pelayanan yang diberikan pada ibu dan anak dengan lengkap di buku KIA, agar ibu dan keluarga lainnya dapat mengetahui dengan pasti kesehatan ibu dan anak. Petugas juga menganjurkan kepada ibu agar setiap kontrol ulang untuk membawa buku KIA, agar bidan dapat mengisi dengan lengkap setelah melakukan pelayanan. Buku KIA yang diisi lengkap memudahkan bidan untuk mendeteksi sedini mungkin adanya risiko atau masalah yang terjadi pada kehamilan dan mengetahui perkembangan serta pertumbuhan bayi. $^{2}$

Buku KIA dapat menjadi suatu alat komunikasi antara tenaga kesehatan dan ibu hamil karena di dalam buku KIA tersebut berisi mengenai catatan-catatan perkembangan ibu hamil seperti keluhan, usia kandungan, hasil pemeriksaan, riwayat persalinan, jenis-jenis pelayanan yang telah didapatkan, riwayat $\mathrm{KB}$, kesehatan, bayi maupun balita, dan lainnya. hal tersebut sesuai dengan tujuan dan manfaat dari buku KIA bagi tenaga kesehatan yaitu sebagai alat pencatatan, pemantauan dan rujukan kesehatan ibu dan anak, alat komunikasi dan penyuluhan KIA, alat untuk mendeteksi secara dini gangguan/masalah KIA. ${ }^{3}$

Manfaat penggunaan buku KIA salah satunya yaitu mendukung terhadap upaya deteksi dini dan antisipasi terjadinya komplikasi kehamilan, persalinan, dan nifas sehingga dapat membantu dalam menurunkan angka kematian ibu (AKI) dan angka kematian bayi (AKB). Seperti pada pelayanan antenatal yang memiliki peranan penting dalam mendeteksi dan tata laksana secara dini jika terjadi komplikasi dalam proses persalinan. Hal ini dapat dijelaskan bahwa jika datang seorang ibu yang bersalin di tenaga kesehatan tanpa mengetahui riwayat pelayanan antenatal sebelumnya, maka akan lebih sulit untuk mengantisipasi faktor risiko dan kemungkinan komplikasi yang terjadi dalam persalinan. ${ }^{4}$

Berdasarkan data Kementerian Kesehatan Indonesia tahun 2017, AKI di Indonesia mencapai 305 per 100.000 kelahiran hidup, AKN sebesar 15 per 1.000 kelahiran hidup (kh) dan AKB 24 per $1.000 \mathrm{kh}$. Hasil tersebut masih jauh dari tujuan capaian MDGs 2015 yaitu AKI sebesar 102 per $100.000 \mathrm{kh}$ dan AKB menjadi 23 per $1.000 \mathrm{kh}$. Dalam RPJMN 2014-2019, pemerintah menargetkan penurunan AKI dari 205/100.000 kelahiran menjadi 276/100.000 kelahiran hidup. Target penurunan AKI secara global pada 2030 berdasarkan Sustainable Development Goals (SDGs) adalah 70 kematian per 100.000 kelahiran hidup. Angka kematian ibu di Indonesia masih cukup tinggi dan meningkat. Hal ini dapat 
terjadi karena adanya kelompok kehamilan berisiko. Kelompok kehamilan risiko tinggi di Indonesia menurut data BKKBN sekitar 34\%. Kategori dengan risiko tinggi mencapai $22,4 \%$, dengan rincian yaitu umur ibu $<18$ tahun sebesar $4,1 \%$, umur ibu > 34 tahun sebesar 3,8\%, jarak kelahiran $<24$ bulan sebesar 5,2\%, dan jumlah anak yang terlalu banyak (>3 orang) sebesar $9,4 \% .^{5}$

Tingginya angka kematian ibu di Indonesia dapat disebabkan karena faktor kunjungan ANC yang masih rendah. Pada tahun 2018 cakupan K1 sebesar 86\% dan K4 adalah $74 \%$. Proporsi tenaga pemberi layanan ANC selama kehamilan oleh bidan sebesar $84,8 \%$. Upaya pertolongan pertama segera dirujuk sebesar $55,3 \%$ dan tidak segera dirujuk sebesar 18,6\%, sementara itu proporsi persalinan oleh tenaga kesehatan sebesar 93,1\%, sedangkan proporsi persalinan di tenaga kesehatan sebesar 79,3\%. ${ }^{5}$

Angka Kematian Ibu di Jawa Barat tahun 2017 sebesar 116/100.000 kelahiran hidup, AKB 3,4/1000 kh atau 3.077 bayi meninggal dan AKN 3,1/1.000 kh (84,63 $\%$ ). Pada tahun 2018 jumlah kematian bayi di Kabupaten Bandung berjumlah 204 kasus dengan penyebab terbanyak Asfiksia 45 kasus (22,06\%), BBLR 98 kasus (48,04\%), TN 2 kasus $(0,98 \%)$ Kelainan kongenital sebanyak 18 kasus $(8,82 \%)$, Ikterus 1 kasus $(0,49 \%)$, Sepsis 8 kasus (3,92\%), Pneumonia 2 kasus $(0,98 \%)$, Diare 1 kasus $(0,49 \%)$ dan sebab lain 29 kasus $(14,22 \%)$ dengan jumlah bayi lahir mati 77 kasus. Angka Kematian Ibu di Kabupaten Bandung tahun pada tahun 2013 mengalami penurunan menjadi 47 kasus dari 57.378 kelahiran hidup, pada tahun 2014 sebanyak 48 kasus dari 64.849 kelahiran hidup, tahun 2015 sebanyak 38 kasus dari 63.021 kelahiran hidup dan tahun 2017 mengalami kenaikan sebanyak 46 kasus dari 62.844 kelahiran hidup, begitupun pada tahun 2018 mengalami penurunan menjadi 39 kasus dari 67.965 kelahiran hidup. ${ }^{7}$

Penyebab kematian ibu bersalin tertinggi di Kabupaten Bandung adalah Perdarahan 48,72\%, diikuti oleh Hipertensi dalam Kehamilan 28,21\%, sebab Lain 17,95\%, Decompensatio Cordis 5,13\% dan Infeksi. Masih adanya kematian ibu dari tahun 2013 sampai dengan tahun 2018 bila dihubungkan dengan penolong persalinan, disebabkan masih adanya pertolongan persalinan oleh dukun (paraji) 7,7\%. Dari 62 Puskesmas ada 31 Puskesmas yang terdapat kasus kematian Ibu hal tersebut di atas terjadi disebabkan karena jasa pelayanan kesehatan yang ada di tingkat dasar (Puskesmas, Polindes) belum dimanfaatkan secara optimal oleh masyarakat, disamping itu ada beberapa desa yang belum memiliki Polindes/ Poskesdes, dan belum semua bidan yang ada di Kabupaten Bandung sudah dilatih APN, persalinan oleh tenaga kesehatan belum mencapai target 90\%, masih terbatasnya sarana pelayanan kesehatan yang mampu menangani kasus kegawatdaruratan Obstetri dan Neonatal yaitu Puskesmas Poned yang ada hanya 16 dan 2 Puskesmas dengan persalinan 24 jam dari 62 Puskesmas yang ada di Kabupaten Bandung. Ditinjau dari faktor perilaku yaitu masih ada persalinan yang ditolong oleh dukun/paraji, di samping itu pengetahuan masyarakat tentang kesehatan masih rendah sehingga keluarga tidak tahu risiko bahaya kehamilan dan persalinan, masih adanya keluarga yang terlambat mencari pertolongan, serta masih ada 
anggapan melahirkan di tenaga kesehatan mahal. $^{7}$

Kasus komplikasi penyebab kematian ini dapat mengancam jiwa, tetapi komplikasi tersebut dapat dicegah dan ditangani bila tenaga kesehatan mampu melakukan identifikasi dini komplikasi. ${ }^{8}$ Penyebab tingginya AKI dan AKB salah satunya adalah adanya 3 keterlambatan yaitu keterlambatan pengambilan keputusan, terlambat merujuk dan terlambat mendapatkan pertolongan. Hal tersebu pada dasarnya dapat dicegah dengan menerapkan Making Pregnancy Safer (MPS) salah satunya yaitu peningkatan deteksi dan penanganan ibu hamil risiko tinggi. Deteksi dini risiko tinggi ibu hamil dilaksanakan tenaga kesehatan bersama masyarakat melalui program Perencanaan Persalinan dan Pencegahan Komplikasi (P4K). ${ }^{9}$ penatalaksanaan deteksi dini maupun kesehatan dan perencanaan kehamilan dan persalinan dapat diketahui dari buku KIA karena berfungsi sebagai alat pemantauan perkembangan kesehatan ibu hamil.

Bidan sebagai salah satu petugas pelaksana sangat besar peranannya dalam pemanfaatan buku KIA, terutama dalam pengisian buku KIA. Oleh karena itu, bidan harus memiliki pengetahuan, sikap, dan perilaku serta tindakan yang baik dalam pemanfaatan buku KIA agar dapat memberikan pelayanan yang terbaik guna mendeteksi lebih dini ibu hamil berisiko tinggi. Dengan adanya pengetahuan yang baik mengenai pemanfaatan buku KIA, maka diharapkan bidan dapat meningkatkan perilakunya dalam pemanfaatan buku KIA sehingga dapat meningkatkan cakupan pelayanan ANC dalam pendeteksian ibu hamil dengan risiko tinggi agar tidak mengalami penyulit atau komplikasi saat kehamilan dan persalinnya.

Berdasarkan permasalahan di atas, maka penelitian ini bertujuan untuk menganalisis pengaruh pengetahuan, sikap, dan perilaku bidan dalam pemanfaatan buku KIA selama periode antenatal terhadap deteksi dini ibu hamil berisiko tinggi di Kecamatan Solokan Jeruk dan Paseh Kabupaten Bandung.

\section{METODE PENELITIAN}

Penelitian ini merupakan penelitian kuantitatif dengan rancangan survei analitik menggunakan desain penelitian cross sectional. Jumlah sampel sebanyak 44 bidan yang terdiri dari 26 bidan di Kecamatan Solokan Jeruk (7 bidan di wilayah Puskesmas Padamukti dan 18 bidan di wilayah Puskesmas Solokan Jeruk) serta 19 bidan di Kecamatan Paseh (10 bidan di wilayah Puskesmas Cipedes dan 9 bidan di wilayah Puskesmas Paseh. Teknik pengambilan sampel menggunakan total sampling dengan kriteria inklusi merupakan Bidan di Wilayah Kerja Puskesmas Padamukti dan Solokan Jeruk di Kecamatan Solokan Jeruk Serta Wilayah Kerja Puskesmas Cipedes dan Paseh di Kecamatan Paseh; berusia 25-60 tahun; berpendidikan DIII - DIV; dan mempunyai pengalaman kerja sebagai bidan Puskesmas minimal 1 tahun. Kriteria kksklusi yaitu subjek yang tidak bersedia menjadi responden penelitian.

Variabel bebas dalam penelitian ini yaitu pengetahuan pemanfaatan buku KIA, sikap dalam pemanfaatan buku KIA, dan perilaku penggunaan buku KIA. Variabel terikat dalam penelitian ini yaitu deteksi dini ibu hamil berisiko tinggi. Variabel perancu dalam penelitian ini yaitu masa kerja, umur, pendidikan, dan pelatihan. 
Jenis dan sumber data yang digunakan dalam penelitian ini adalah data primer yaitu data yang diambil langsung dari responden melalui pengisian kuesioner (pengetahuan, sikap) dan melakukan observasi kepada responden (perilaku dan deteksi dini). Alat ukur pengetahuan dan perilaku diadaptasi dari buku instrumen evaluasi petugas kesehatan pasca orientasi buku KIA di tempat pelayanan dari Departemen Kesehatan RI. ${ }^{10}$ Alat ukur deteksi dini menggunakan kartu studi kasus dari skrining risiko tinggi kehamilan dari Rochyati. ${ }^{11}$ Alat ukur sikap dibuat sendiri oleh peneliti dan telah dilakukan uji validitas dan reliabilitas, dimana didapatkan nilai validitasnya antara 0,448 sampai $0,718>\mathrm{r}$ tabel 0,433 dengan nilai alpha 0,877 .

Data hasil penelitian dianalisis secara univariat untuk menggambarkan distribusi frekuensi dari karaktertistik responden (masa kerja, umur, pendidikan, dan pelatihan), pengetahuan, sikap, perilaku, dan deteksi dini ibu hamil berisiko tinggi. Analisis bivariat digunakan untuk mengungkapkan hubungan antar variabel bebas dengan terikat yaitu hubungan antara pengetahuan, sikap, dan perilaku dengan deteksi dini ibu hamil berisiko tinggi yang dilakukan oleh bidan yang diuji menggunakan chi square. Analisis multivariat digunakan untuk menguji hipotesis dan menganalisis pengaruh pengetahuan, sikap, dan perilaku terhadap deteksi dini ibu hamil berisiko tinggi menggunakan regresi logistik berganda, serta menguji pengaruh secara simultan pengaruh pengetahuan, sikap, dan perilaku terhadap deteksi dini ibu hamil berisiko tinggi dilihat dari nilai $\mathrm{p}$, dimana besarnya kontribusi variabel independen terhadap dependen secara simultan dilihat pada nilai Nagelkerke $R$ Square.

\section{HASIL DAN PEMBAHASAN}

Berdasarkan tabel 1, sebagian besar responden dengan masa kerja $<5$ tahun $(71,4 \%)$ dan masa kerja 5-9 tahun $(62,5 \%)$ melakukan deteksi dini kurang baik sedangkan responden dengan masa kerja $>9$ tahun $(65,5 \%)$ melakukan deteksi dini dengan baik. Sebagian besar responden dengan usia $<30$ tahun $(71,4 \%)$ dan usia 30-39 tahun (50\%) melakukan deteksi dini kurang baik sedangkan responden dengan usia >39 tahun $(66,7 \%)$ melakukan deteksi dini dengan baik. Lebih dari sebagian responden pendidikan DIII (54,5\%) melakukan deteksi dini dengan baik. Sebagian besar responden belum pernah mengikuti pelatihan $(71,4 \%)$ melakukan deteksi dini kurang baik sedangkan responden yang pernah mengikuti pelatihan $(59,5 \%)$ melakukan deteksi dini dengan baik.

Tabel 1 Karakteristik Responden Berdasarkan Masa Kerja, Umur, Pendidikan, dan Pelatihan Terhadap Deteksi Dini Ibu Hamil Berisiko

\begin{tabular}{lcc}
\hline \multirow{2}{*}{ Karakteristik } & \multicolumn{2}{c}{ Deteksi Dini Ibu Hamil Berisiko Tinggi } \\
\cline { 2 - 3 } Masa Kerja (Tahun) & Kurang Baik $(\mathrm{n}=20)$ & Baik(n=24) \\
$\quad<5$ & $5(71,4 \%)$ & $2(28,6 \%)$ \\
$5-9$ & $5(62,5 \%)$ & $3(37,5 \%)$ \\
$\quad>9$ & $10(34,5 \%)$ & $19(65,5 \%)$ \\
Umur (Tahun) & $5(71,4 \%)$ & $2(28,6 \%)$
\end{tabular}




\begin{tabular}{ccc}
$30-39$ & $8(50 \%)$ & $8(50 \%)$ \\
$>39$ & $7(33,3 \%)$ & $14(66,7 \%)$ \\
Pendidikan & & \\
DIII & $20(45,5 \%)$ & $24(54,5 \%)$ \\
DIV & $0(0 \%)$ & $0(0 \%)$ \\
Pelatihan & & \\
Belum Pernah & $5(71,4 \%)$ & $2(28,6 \%)$ \\
Pernah & $15(40,5 \%)$ & $22(59,5 \%)$ \\
\hline
\end{tabular}

Tabel 2 Hubungan Pengetahuan, Sikap, dan Perilaku Bidan dalam Pemanfaatan Buku KIA Terhadap Deteksi Dini Ibu Hamil Berisiko Tinggi

\begin{tabular}{|c|c|c|c|c|}
\hline \multirow{2}{*}{ Variabel } & \multicolumn{2}{|c|}{$\begin{array}{c}\text { Deteksi Dini Ibu Hamil Berisiko } \\
\text { Tingi }\end{array}$} & \multirow{2}{*}{ Nilai p } & \multirow{2}{*}{ RP (IK 95\%) } \\
\hline & $\begin{array}{c}\begin{array}{c}\text { Kurang Baik } \\
(\mathbf{n}=20)\end{array} \\
\end{array}$ & $\begin{array}{c}\text { Baik } \\
(\mathrm{n}=\mathbf{2 4})\end{array}$ & & \\
\hline \multicolumn{5}{|l|}{ Pengetahuan } \\
\hline Cukup & $11(64,7 \%)$ & $6(35,3 \%)$ & 0,042 & $1,941(1,025-3,676)$ \\
\hline Baik & $9(33,3 \%)$ & $18(66,7 \%)$ & & \\
\hline \multicolumn{5}{|l|}{ Sikap } \\
\hline Kurang Baik & $10(71,4 \%)$ & $4(28,6 \%)$ & 0,018 & $2,143(1,170-3,924)$ \\
\hline Baik & $10(33,3 \%)$ & $20(66,7 \%)$ & & \\
\hline \multicolumn{5}{|l|}{ Perilaku } \\
\hline Kurang Baik & $11(73,3 \%)$ & $4(26,7 \%)$ & 0,008 & $2,363(1,268-4,404)$ \\
\hline Baik & $9(31 \%)$ & $20(69 \%)$ & & \\
\hline
\end{tabular}

Keterangan: Nilai p dihitung berdasarkan uji chi square

Berdasarkan tabel 2 diketahui sebagian besar responden dengan pengetahuan cukup melakukan deteksi dini ibu hamil risiko tinggi dengan kurang baik sebanyak 11 orang $(64,7 \%)$, sedangkan responden dengan pengetahuan baik melakukan deteksi dini ibu hamil berisiko dengan baik sebanyak 6 orang $(35,3 \%)$. Hasil uji statistik chi square menunjukkan terdapat hubungan antara pengetahuan bidan dalam pemanfaatan buku KIA dengan deteksi dini ibu hamil berisiko tinggi $(p \geq 0,05)$. Responden dengan pengetahuan cukup dalam pemanfaatan buku KIA berpeluang 1,941 kali untuk melakukan deteksi dini ibu hamil berisiko tinggi yang kurang baik, dibandingkan dengan responden yang berpengetahuan baik.
Pada hubungan sikap dengan deteksi dini diketahui sebagian besar responden dengan sikap kurang baik melakukan deteksi dini ibu hamil berisiko tinggi dengan kurang baik sebanyak 10 orang $(71,4 \%)$, sedangkan responden dengan sikap baik melakukan deteksi dini ibu hamil berisiko tinggi dengan baik sebanyak 20 orang $(66,7 \%)$. Hasil uji $C h i$ Square menunjukkan terdapat hubungan antara sikap bidan dalam pemanfaatan buku KIA dengan deteksi dini ibu hamil berisiko tinggi $(\mathrm{p}<0,05)$. Responden dengan sikap kurang baik dalam pemanfaatan buku KIA berpeluang 2,143 kali untuk melakukan deteksi dini ibu hamil berisiko tinggi kurang baik, dibandingkan dengan responden yang mempunyai sikap baik. 
Pada hubungan perilaku dengan deteksi dini diketahui bahwa sebagian besar responden dengan perilaku kurang baik dalam penggunaan buku KIA melakukan deteksi dini ibu hamil berisiko tinggi dengan kurang baik sebanyak 11 orang $(73,3 \%)$, sedangkan sebagian besar responden dengan perilaku yang baik dalam penggunaan buku KIA melakukan deteksi dini ibu hamil berisiko tinggi dengan baik sebanyak 20 orang (69\%).

Tabel 3 Pengaruh Pengetahuan, Sikap, dan Perilaku Bidan dalam Pemanfaatan Buku KIA Terhadap Deteksi Dini Ibu Hamil Berisiko Tinggi Secara Simultan
Hasil uji Chi Square menunjukkan terdapat hubungan perilaku bidan dalam penggunaan buku KIA dengan deteksi dini ibu hamil berisiko tinggi $(\mathrm{p}<0,05)$. Responden dengan perilaku kurang baik dalam penggunaan buku KIA berpeluang 2,363 kali untuk melakukan deteksi dini ibu hamil berisiko tinggi kurang baik, dibandingkan dengan responden yang mempunyai perilaku baik.

\begin{tabular}{lcccc}
\hline \multicolumn{1}{c}{ Variabel } & Koefisien B & S.E & Nilai p & POR (IK 95\%) \\
\hline Pengetahuan (Cukup) & 1,421 & 0,783 & 0,070 & $4,139(0,892-19,214)$ \\
Sikap (Kurang Baik) & 1,793 & 0,829 & 0,031 & $6,010(1,184-30,516)$ \\
Perilaku (Kurang & 2,213 & 0,835 & 0,008 & $9,147(1,779-47,035)$ \\
Baik) & & & & \\
\hline
\end{tabular}

Keterangan: Nilai p didapatkan dari hasil uji regresi logistik

$\mathrm{R}^{2}$ (Nagelkerke) $=43,5 \%$ dengan nilai $\mathrm{p}$ Simultan 0,001

POR $($ IK 95\%) = Prevalensi Odds Rasio dan Interval Kepercayaan 95\%

Berdasarkan data hasil penelitian, diketahui tidak terdapat pengaruh pengetahuan bidan mengenai pemanfaatan buku terhadap deteksi dini ibu hamil berisiko tinggi di Kecamatan Solokan Jeruk dan Paseh Kabupaten Bandung. Hal tersebut dikarenakan dari hasil uji statistik didapatkan nilai $\mathrm{p} 0,070(\mathrm{p} \geq 0,05)$ dan mempunyai nilai POR 4,139 dengan nilai interval kepercayaan 95\% sebesar 0,89219,214 dimana nilai IK 95\% tersebut melewati angka 1. Hal ini menjelaskan pengetahuan bidan mengenai pemanfaatan buku KIA bukan merupakan salah satu faktor yang berpengaruh deteksi dini ibu hamil berisiko tinggi.

Pada penelitian ini walaupun secara regresi menunjukkan tidak adanya pengaruh pengetahuan terhadap deteksi dini ibu hamil berisiko tinggi, akan tetapi secara korelasi menunjukkan bahwa terdapat hubungan bermakna antara pengetahuan bidan dalam pemanfaatan buku KIA dengan deteksi dini ibu hamil berisiko tinggi. Didapatkan nilai PR 1,941, artinya bidan dengan pengetahuan kurang baik mengani pemanfaatan buku KIA berpeluang 1,941 kali lebih besar untuk melakukan deteksi dini ibu hamil berisiko tinggi dengan kurang baik. Hal ini menjelaskan bahwa secara korelasi pengetahuan berhubungan dengan deteksi dini ibu hamil berisiko, akan tetapi secara regresi tidak berpengaruh. Hal ini dapat berkaitan dengan adanya variabel yang lain yang dapat mempengaruhi pengetahuan. Hal tersebut dikarenakan pengetahuan adalah domain kognitif dari perilaku, yang selanjutnya perilaku tidak hanya dipengaruhi oleh pengetahuan saja, melainkan oleh sikap ataupun perilaku atau tindakan. 
Pengetahuan penting untuk terbentuknya perilaku seseorang (overt behavior). ${ }^{12}$ Pengetahuan mengenai pemanfaatan buku KIA menjadi dasar bagi ketaatan bidan dalam melaksanakan pedoman kerja sebagai upaya pemantauan dan deteksi dini risiko tinggi kehamilan. Semakin baik pengetahuan bidan dalam pemantauan dan deteksi dini risiko tinggi kehamilan, maka perilaku bidan juga akan semakin aktif dalam melakukan pemantauan dan deteksi dini risiko tinggi kehamilan. ${ }^{13,14,15}$ Pengetahuan mengenai tanda bahaya selama kehamilan berkaitan dengan keterlambatan untuk mengenali dan mengatasi tanda bahaya dan komplikasi yang terjadi pada ibu hamil. ${ }^{1}$ Petugas yang tidak melaksanakan pencatatan karena tidak memahami buku KIA secara keseluruhan. ${ }^{3}$

Hasil penelitian ini didukung oleh penelitian Suparni yang menjelaskan bahwa tidak ada hubungan bermakna pengetahuan bidan dalam pemanfaatan buku KIA untuk deteksi dini ibu hamil risiko tinggi. ${ }^{13}$ hal yang sama dengan penelitian Nopitawati yang menjelaskan bahwa pengetahuan tidak berpengaruh terhadap deteksi dini ibu hamil resiko tinggi melalui pemanfaatan buku KIA. ${ }^{16}$

Berbeda dengan penelitian yang dilakukan Khadijah yang menjelaskan bahwa ini determinan yang berhubungan dengan upaya deteksi dini risiko tinggi kehamilan adalah pengetahuan (p 0.008). ${ }^{14}$ Penelitian Azissah menjelaskan bahwa terdapat hubungan antara pengetahuan dengan peran bidan dalam pemantauan dan deteksi dini risiko tinggi kehamilan. Semakin baik pengetahuan yang dimiliki oleh bidan maka akan semakin baik pula dalam melakukan deteksi dini risiko tinggi kehamilan. ${ }^{15}$ Penelitian Puspaningtyas menjelaskan pengetahuan merupakan salah satu faktor yang mempengaruhi bidan dalam pemanfaatan buku KIA sebagai deteksi dini ibu hamil berisiko. ${ }^{2}$

Berdasarkan penjelasan di atas, dapat diketahui bahwa pengetahuan tidak mempengaruhi bidan dalam melaksanakan deteksi dini ibu hamil berisiko tinggi. Hal ini dikarenakan sebagian besar pengetahuan bidan mengenai pemanfaatan buku KIA sudah baik. Selain itu, tindakan bidan dalam melakukan deteksi dini ibu hamil berisiko tinggi dapat dipengaruhi oleh faktor lain seperti motivasi, kebiasaan dalam mematuhi prosedur, beban kerja, sarana prasarana, pengawasan, dan sebagainya. Maka dari itu diperlukan suatu usaha dalam meningkatkan pelaksanaan deteksi dini pada bidan dengan cara melakukan pengawasan dalam pelaksanaan deteksi dini ibu hamil berisiko tinggi.

Berdasarkan data hasil penelitian, dapat diketahui bahwa terdapat pengaruh sikap bidan dalam pemanfaatan buku terhadap deteksi dini ibu hamil berisiko tinggi di Kecamatan Solokan Jeruk dan Paseh Kabupaten Bandung. Hal tersebut dikarenakan dari hasil uji statistik didapatkan nilai p 0,018 ( $\mathrm{p}<0,05)$. Hal ini menjelaskan bahwa sikap bidan dalam pemanfaatan buku KIA merupakan salah satu faktor yang berpengaruh deteksi dini ibu hamil berisiko tinggi, dimana bidan yang memiliki sikap kurang baik memiliki peluang lebih besar untuk melakukan deteksi dini ibu hamil berisiko tinggi dengan kurang baik dibandingkan responden dengan bidan yang mempunyai sikap yang baik..

Adanya pengaruh sikap bidan dalam pemanfaatan buku terhadap deteksi dini ibu hamil berisiko tinggi tersebut 
dapat terlihat dari data hasil penelitian dimana dari 14 orang dengan sikap kurang baik sebagian besar melakukan deteksi dini dengan kurang baik sebanyak 10 orang $(71,4 \%)$ dan 4 orang $(28,6 \%)$ melakukan deteksi dini ibu hamil berisiko dengan baik, sedangkan dari 30 orang dengan sikap yang baik sebagian besar melakukan deteksi dini ibu hamil berisiko dengan baik sebanyak 20 orang $(66,7 \%)$ dan 10 orang $(33,3 \%)$ melakukan deteksi dini ibu hamil berisiko dengan kurang baik. Hal ini menjelaskan bahwa semakin baik sikap bidan dalam pemanfaatan buku KIA maka akan semakin baik pula dalam mendeteksi dini ibu hamil berisiko, dan sebaliknya semakin kurang baik sikap bidan dalam pemanfaatan buku KIA maka akan semakin kurang baik pula dalam mendeteksi dini ibu hamil berisiko.

Sikap merupakan respon tertutup seseorang terhadap stimulus atau objek tertentu yang sudah melibatkan faktor pendapat dan emosi yang bersangkutan. Manifestasi sikap tidak dapat langsung dilihat, tetapi hanya dapat ditafsirkan terlebih dahulu dari perilaku tertutup. ${ }^{12}$ Sikap memengaruhi tindakan lewat suatu proses pengambilan keputusan yang teliti dan beralasan yang dampaknya terbatas. ${ }^{17}$ Penggunaan buku KIA dapat mendukung terhadap upaya deteksi dini dan antisipasi terjadinya komplikasi. ${ }^{5}$ Dukungan dapat terbentuk karena adanya minat, dan minat seseorang untuk melakukan perilaku tertentu dipengaruhi oleh keyakinan yang mendukung aspek pengetahuan. ${ }^{18}$ Sikap mengandung tiga komponen terdiri dari komponen kognitif (cognitive), afektif (affective) dan perilaku (tindakan). ${ }^{17}$

Sikap bidan dapat diartikan sebagai suatu pandangan atau penilaian terhadap pelaksanaan pelayanan antenatal dan penggunaan buku KIA dalam usaha melakukan deteksi dini ibu hamil berisiko, dimana seorang bidan apakah mempunyai pandangan seberapa penting tentang pelaksanaan tersebut. Berkaitan dengan komponen kognitif, dalam hal ini bidan apakah mempunyai pandangan yang baik dan menganggap seberapa pentingkah mengenai pemanfaatan buku KIA dalam pelaksanaan ANC untuk mendeteksi dini ibu hamil berisiko. Setelah bidan mempunyai pemahaman atau pengetahuan terhadap pemanfaatan buku KIA, maka selanjutnya bidan secara tidak langsung akan mempunyai pandangan tentang pentingnya memanfaatkan buku KIA dan secara tidak langsung hal tersebut secara emosional akan mengolahnya menjadi suatu penilaian atau pertimbangan terhadap masalah tersebut.

Seorang bidan akan menunjukkan sikap bagaimana kecenderungan bidan dalam melakukan tindakan. Seperti contohnya menganggap pentingnya untuk mengisi buku KIA karena sebagai bahan informasi. Dengan adanya pengetahuan, sikap emosional, maka seorang bidan akan cenderung mempunyai sikap untuk bertindak dengan baik dan menganggap hal tersebut penting.

Hasil penelitian ini didukung oleh penelitian Khadijah yang menjelaskan bahwa ada hubungan yang signifikan antara sikap dengan peran bidan dalam pemantauan dan deteksi dini risiko tinggi kehamilan (p 0,012). ${ }^{14}$ Hal yang sama dengan penelitian Azissah yang menjelaskan bahwa ada hubungan yang signifikan antara sikap dengan peran bidan dalam pemantauan dan deteksi dini risiko tinggi kehamilan. Semakin baik sikap yang dimiliki oleh bidan maka akan semakin baik pula dalam melakukan deteksi dini 
risiko tinggi kehamilan. ${ }^{15}$ Penelitian Puspaningtyas menjelaskan bahwa ada hubungan antara sikap dengan dalam pemanfaatan buku KIA sebagai deteksi dini ibu hamil berisiko. ${ }^{2}$ Penelitian Rulihari menjelaskan bahwa ada hubungan antara sikap dengan deteksi dini ibu hamil risiko tinggi. ${ }^{19}$

Berdasarkan uraian di atas, dapat disimpulkan bahwa sikap berpengaruh terhadap deteksi dini ibu hamil berisiko tinggi. Sikap akan mewujudkan suatu persepsi atau pandangan yang pada akhirnya akan membentuk suatu perilaku. Hal ini berkaitan dengan pandangan atau sikap bidan dalam memanfaatkan buku KIA apakah penting atau tidak sehingga secara tidak langsung akan mempengaruhi bagaimana tindakan bidan dalam melakukan deteksi dini.

Berdasarkan data hasil penelitian, dapat diketahui terdapat pengaruh perilaku penggunaan buku KIA oleh bidan terhadap deteksi dini ibu hamil berisiko tinggi di Kecamatan Solokan Jeruk dan Paseh Kabupaten Bandung. Hal tersebut dikarenakan dari hasil uji statistik didapatkan nilai p 0,008 ( $\mathrm{p}<0,05)$. Hal ini menjelaskan bahwa perilaku bidan dalam penggunaan buku KIA merupakan salah satu faktor yang berpengaruh deteksi dini ibu hamil berisiko tinggi, dimana bidan yang memiliki perilaku kurang baik memiliki peluang lebih besar untuk melakukan deteksi dini ibu hamil berisiko tinggi dengan kurang baik dibandingkan responden dengan bidan yang mempunyai perilaku yang baik.

Adanya pengaruh perilaku bidan dalam pemanfaatan buku terhadap deteksi dini ibu hamil berisiko tinggi tersebut dapat terlihat dari data hasil penelitian dimana diketahui bahwa dari 15 orang dengan perilaku yang kurang baik dalam penggunaan buku KIA sebagian besar melakukan deteksi dini ibu hamil berisiko dengan kurang baik sebanyak 11 orang $(73,3 \%)$, sedangkan dari 27 orang dengan perilaku yang baik dalam penggunaan buku KIA sebagian besar melakukan deteksi dini ibu hamil berisiko dengan baik sebanyak 20 orang (69\%). Hal ini menjelaskan bahwa semakin baik perilaku bidan dalam penggunaan buku KIA maka akan semakin baik pula dalam mendeteksi dini ibu hamil berisiko.

Perilaku merupakan bagian dari bentuk nyata suatu tindakan atau praktik. Tindakan adalah realisasi dari pengetahuan dan sikap suatu perbuatan nyata sebagai respon seseorang terhadap stimilus dalam bentuk nyata atau terbuka. Setelah seseorang mengetahui stimulus atau objek kesehatan, kemudian mengadakan penilaian atau pendapat terhadap apa yang diketahui, proses selanjutnya diharapkan ia akan melaksanakan atau mempraktikkan apa yang diketahui atau disikapinya (dinilai baik). Suatu rangsangan akan direspon oleh seseorang sesuai dengan arti rangsangan itu bagi orang yang bersangkutan. Respon atau reaksi ini disebut perilaku, bentuk perilaku dapat bersifat sederhana dan kompleks. ${ }^{20}$

Perilaku bidan dalam penggunaan buku KIA merupakan tindakan nyata atau praktik bidan dalam melakukan pemeriksaan kehamilan, memanfaatkan dan menggunakan buku KIA dengan baik dan benar serta mampu mendeteksi dini ibu hamil yang berisiko tinggi. Perilaku tersebut pada dasarnya dapat terbentuk jika bidan mempunyai pengetahuan dan sikap yang baik. Perilaku bidan dalam penggunaan buku KIA dapat membantu bidan dalam mendeteksi lebih dini jika ibu 
hamil mengalami masalah atau berisiko pada kehamilannya.

Buku KIA dapat mencatat adanya gangguan yang terjadi pada ibu hamil. Penggunaan buku KIA dapat digunakan sebagai alat untuk mendeteksi secara dini adanya gangguan atau masalah kesehatan ibu dan anak. ${ }^{3}$ Buku KIA yang diisi lengkap akan memudahkan bidan untuk mendeteksi sedini mungkin adanya risiko atau masalah yang terjadi pada kehamilan dan mengetahui tumbuh kembang bayi. ${ }^{2}$

Hasil penelitian ini didukung oleh penelitian Marniyati yang menjelaskan bahwa perilaku dapat berkaitan dalam meningkatkan deteksi risiko tinggi pada ibu hamil oleh tenaga kesehatan. ${ }^{21} \mathrm{Hal}$ yang sama dengan penelitian Utami yang menjelaskan bahwa perilaku berhubungan dengan praktik deteksi dini pada ibu hamil risiko tinggi oleh bidan. ${ }^{22}$

Berdasarkan uraian di atas, perilaku berpengaruh terhadap deteksi dini ibu hamil berisiko tinggi. Perilaku merupakan wujud nyata dari sebuah tindakan dimana dalam hal ini bidan melakukan pemeriksaan ANC dengan memanfaatkan atau menggunakan buku KIA sebagai deteksi dini ibu hamil berisiko tinggi. Bidan dengan perilaku yang baik dan mampu melakukan deteksi dini dikarenakan mereka mempunyai kebiasaan dalam melakukan pemeriksaan ANC dengan baik, benar dan tepat. Hal tersebut pada dasarnya dapat terwujud jika seorang bidan mempunyai pengetahuan dan sikap yang baik pula.

Berdasarkan data hasil penelitian, dapat diketahui bahwa terdapat pengaruh secara simultan antara pengetahuan, sikap, dan perilaku bidan dalam pemanfaatan buku KIA terhadap deteksi dini ibu hamil berisiko tinggi di Kecamatan Solokan
Jeruk dan Paseh Kabupaten Bandung. Hal tersebut dikarenakan dari hasil uji statistik didapatkan nilai p 0,001 ( $p<0,05)$. Hal ini menjelaskan bahwa pengetahuan, sikap, dan perilaku bidan dalam pemanfaatan buku KIA secara bersamaan berpengaruh secara nyata terhadap deteksi dini ibu hamil berisiko tinggi, dimana ketiga variabel tersebut (pengetahuan, sikap, dan perilaku) sebesar $43,5 \%$ berkontribusi atau mempengaruhi deteksi dini ibu hamil berisiko tinggi.

Hasil penelitian tersebut menjelaskan bahwa semakin baik pengetahuan yang dimiliki oleh bidan yang ditunjang dengan sikap yang baik serta perilaku bidan dalam penggunaan buku KIA yang baik akan meningkatkan pelaksanaan deteksi dini ibu hamil berisiko tinggi dengan baik. Hal tersebut dikarenakan dengan semakin baiknya pengetahuan, maka secara tidak langsung akan mempengaruhi bagaimana sikap bidan dalam pemanfaatan buku KIA. Selain itu, dengan pengetahuan dan sikap yang baik akan melahirkan atau menimbulkan suatu perilaku yang baik.

Hal tersebut sesuai dengan data hasil penelitian dimana responden dengan pengetahuan cukup namun dengan sikap dan perilaku yang baik seluruhnya melakukan deteksi dini ibu hamil berisiko dengan baik sebanyak 2 orang (100\%). Responden dengan pengetahuan dan perilaku yang baik namun dengan sikap yang kurang baik sebagian besar melakukan deteksi dini ibu hamil berisiko dengan baik sebanyak 4 orang $(57,1 \%)$. Responden dengan pengetahuan, sikap dan perilaku yang baik seluruhnya melakukan deteksi dini ibu hamil berisiko dengan baik sebanyak 11 orang (100\%). 
Responden dengan pengetahuan yang cukup, serta sikap dan perilaku yang kurang baik seluruhnya melakukan deteksi dini ibu hamil berisiko dengan kurang baik sebanyak 3 orang (100\%). Responden dengan pengetahuan yang cukup, serta sikap kurang baik namun mempunyai perilaku yang baik sebagian besar melakukan deteksi dini ibu hamil berisiko dengan kurang baik sebanyak 6 orang $(66,7 \%)$. Responden dengan pengetahuan yang cukup, serta perilaku kurang baik namun mempunyai sikap yang baik sebagian besar melakukan deteksi dini ibu hamil berisiko dengan kurang baik sebanyak 2 orang $(66,7 \%)$. Responden dengan pengetahuan yang baik namun dengan sikap dan perilaku yang kurang baik sebagian besar melakukan deteksi dini ibu hamil berisiko dengan kurang baik sebanyak 3 orang (75\%). Responden dengan pengetahuan dan sikap yang baik namun dengan perilaku yang kurang baik sebagian besar melakukan deteksi dini ibu hamil berisiko dengan kurang baik sebanyak 3 orang $(60 \%)$.

Pelaksanaan deteksi dini pada ibu hamil berisiko tinggi sangat penting dilakukan untuk mencegah terjadinya komplikasi pada ibu hamil. Hal tersebut tentunya harus didukung dengan pengetahuan, sikap, dan perilaku bidan yang baik dalam pemanfaatan buku KIA sebagai usaha dalam melakukan deteksi dini ibu hamil berisiko tinggi. Menurut Widiastuti, untuk meningkatkan pengetahuan, sikap, dan perilaku dalam melakukan deteksi dini diperlukan manajemen deteksi dini. Manajemen deteksi dini pada ibu hamil risiko tinggi tersebut dapat dipengaruhi oleh perencanaan, pembinaan, dan supervisi/ monitoring. Maka dari itu diperlukan suatu perencanaan, pembinaan, supervisi dan monitoring secara lebih intensif kepada bidan untuk meningkatkan pelaksanaan deteksi dini ibu hamil berisiko tinggi. ${ }^{23}$

Hasil penelitian ini didukung oleh penelitian yang dilakukan Puspaningtyas yang menjelaskan pengetahuan secara bersamaan berpengaruh dalam pemanfaatan buku KIA sebagai deteksi dini ibu hamil berisiko. ${ }^{2}$ hal yang sama dengan penelitian Rulihari yang menjelaskan bahwa ada sikap secara bersamaan berhubungan dengan deteksi dini ibu hamil risiko tinggi. ${ }^{19}$

Penjelasan di atas menegaskan bahwa pengetahuan, sikap dan perilaku satu sama lain saling berkaitan dalam mempengaruhi bidan melakukan deteksi dini ibu hamil berisiko dengan baik, dimana sikap dan perilaku menunjukkan faktor yang paling dominan yang berpengaruh terhadap deteksi dini ibu hamil berisiko tinggi.

\section{KESIMPULAN}

Berdasarkan hasil data penelitian dan pembahasan, maka dapat diambil kesimpulan bahwa responden dengan masa kerja $>9$ tahun $(65,5 \%)$, usia $>39$ tahun $(66,7 \%)$, pendidikan DIII $(54,5 \%)$, pernah mengikuti pelatihan $(59,5 \%)$, berpengetahuan baik dalam pemanfaatan buku KIA $(66,7 \%)$, sikap baik dalam pemanfaatan buku KIA $(66,7 \%)$, dan perilaku baik dalam penggunaan buku KIA (69\%) melakukan deteksi dini dengan baik. Terdapat hubungan antara pengetahuan $(\mathrm{p}=0,042)$, sikap $(\mathrm{p}=0,018)$, dan perilaku $(\mathrm{p}=0,008)$ bidan dalam pemanfaatan buku KIA terhadap deteksi dini ibu hamil berisiko tinggi di Kecamatan Solokan Jeruk dan Paseh Kabupaten Bandung. 
Tidak terdapat pengaruh pengetahuan bidan dalam pemanfaatan buku KIA terhadap deteksi dini ibu hamil berisiko tinggi di Kecamatan Solokan Jeruk dan Paseh Kabupaten Bandung $(\mathrm{p}=0,070)$. Terdapat pengaruh sikap bidan dalam pemanfaatan buku KIA $(\mathrm{p}=0,031)$ dan perilaku penggunaan buku KIA $(\mathrm{p}=0,008)$ terhadap deteksi dini ibu hamil berisiko tinggi di Kecamatan Solokan Jeruk dan Paseh Kabupaten Bandung ( $\mathrm{p}<$ $0,05)$. Terdapat pengaruh secara simultan antara pengetahuan, sikap, dan perilaku bidan dalam pemanfaatan buku KIA terhadap deteksi dini ibu hamil berisiko tinggi di Kecamatan Solokan Jeruk dan Paseh Kabupaten Bandung $\quad(\mathrm{p}=0,001$; $\left.\mathrm{R}^{2}=0,435\right)$.

\section{UCAPAN TERIMA KASIH}

Penulis mengucapkan terima kasih kepada Dinas Kesehatan Kabupaten Bandung, Puskesmas Padamukti, Puskesmas Solokan Jeruk, Puskesmas Cipedes, Puskesmas Paseh atas ijin yang diberikan untuk melaksanakan penelitian. Selain itu penulis juga mengucapkan terima kasih kepada seluruh responden yang telah berpartisipasi pada penelitian ini.

\section{DAFTAR PUSTAKA}

1. Mintarsih W. Replikasi kegiatan pemanfaatan buku kia melalui pendampingan mahasiswa dan kader kesehatan. J Ilm Bidan [Internet]. 2018;3(3):1-10. Available from: https://www.e-

journal.ibi.or.id/index.php/jib/article/d ownload/70/64/

2. Puspaningtyas $\mathrm{M}$, Meikawati PR, Masyunah Y. Analisis kinerja dalam pemanfaatan Buku KIA oleh Bidan di Puskesmas Kabupaten Pekalongan. Kajen [Internet]. 2017;1(1):15-24.
Available from: https://jurnal.pekalongankab.go.id/ass ets/files/20-02-2018_analisis_1524.pdf

3. Kementerian Kesehatan Republik Indonesia. Petunjuk Teknis Penggunaan Buku Kesehatan Ibu dan Anak. Jakarta: Departemen Kesehatan dan JICA (Japan International Cooperation Agency); 2015.

4. Kementerian Kesehatan Republik Indonesia. Profil Kesehatan Indonesia Tahun 2016. Jakarta; 2017.

5. Kementerian Kesehatan Republik Indonesia. Profil Kesehatan Indonesia Tahun 2017. Jakarta; 2018.

6. Dinkes Jawa Barat. Profil Kesehatan Provinsi Jawa Barat Tahun 2017. Bandung: Dinas Kesehatan Provinsi Jawa Barat; 2018.

7. Dinas Kesehatan Kabupaten Bandung. Profil Kesehatan Kabupaten Bandung Tahun 2018. Kabupaten Bandung; 2018.

8. Kementerian Kesehatan Republik Indonesia. Rencana Aksi Percepatan Penurunan Angka Kematian Ibu Di Indonesia Tahun 2013-2015. Jakarta; 2015.

9. Kementerian Kesehatan Republik Indonesia. Pedoman Program Perencanaan Persalinan dan Pencegahan Komplikasi dengan Stiker: Dalam Rangka Mempercepat Penurunan AKI. Jakarta; 2010.

10. Kementerian Kesehatan Republik Indonesia. Instrumen Evaluasi Petugas Kesehatan pasca Orientasi Buku KIA Di Tempat Pelayanan. Jakarta: Departemen Kesehatan RI bekerja sama dengan Japan International Cooperation Agency; 2008.

11. Rochyati P. Skrining Antenatal pada Ibu Hamil: Pengenalan Faktor Risiko. Surabaya: Airlangga; 2003. 
12. Notoatmodjo S. Promosi Kesehatan dan Perilaku Kesehatan. Jakarta: Rineka Cipta; 2012. 18-201 p.

13. Suparni, Khanifah M, Fitriyani. Faktor-faktor yang berhubungan dengan pengetahuan bidan dalam pemanfaatan buku KIA untuk deteksi dini ibu hamil risiko tinggi di Kabupaten Pekalongan Tahun 2016. 2016;49-62.

14. Khadijah S, . A. Upaya deteksi dini resiko tinggi kehamilan ditentukan oleh pengetahuan dan dukungan tenaga kesehatan. J Sehat Mandiri. 2018;13(1):27-34.

15. Azissah D, Wulansari D. Faktorfaktor yang berhubungan dengan peran bidan dalam pemantauan dan deteksi dini resiko tinggi kehamilan di wilayah kerja Puskesmas Basuki Rahmat Kota Bengkulu. J Keperawatan Silampari. 2018 Dec;2(1):184-202.

16. Nopitawati. Kinerja Bidan Dalam Deteksi Dini Ibu Hamil Resiko Tinggi Melalui Pemanfaatan Buku Kia Di Wilayah Dinas Kesehatan Kabupaten Katingan Propinsi Kalimantan Tengah Tahun 2013 [Internet]. [Semarang]: Universitas Diponegoro; 2013. Available from: http://eprints.undip.ac.id/43373/

17. Sobur A. Psikologi Umum: dalam Lintasan Sejarah. Bandung: Pustaka Setia; 2013. 355-398 p.

18. Menkes. Keputusan Menteri Kesehatan Republik Indonesia Nomor 284/Menkes/SK/III/2004 Tentang Buku Kesehatan Ibu Dan Anak (KIA). 2004.

19. Rulihari S, Kartasurya MI, Sriatmi A. Faktor-faktor yang Berhubungan dengan Kinerja Bidan dalam Penggunaan Skor "Poedji Rochjati" pada Deteksi Risiko Ibu Hamil (Studi pada Bidan Praktek Swasta di
Kabupaten Gresik). J Manaj Kesehat Indones. 2014;02(1):71-82.

20. Irwan. Etika dan Perilaku Kesehatan. Yogyakarta: CV. Absolute Media; 2017.

21. Marniyati L, Saleh I, Bambang B, Soebyakto. Pelayanan Antenatal Berkualitas dalam Meningkatkan Deteksi Risiko Tinggi pada Ibu Hamil oleh Tenaga Kesehatan di Puskesmas Sako, Sosial, Sei Baung dan Sei Selincah di Kota Palembang. J Kedokt dan Kesehat. 2016;3(1):355-62.

22. Utami SB. Faktor-faktor yang Berhubungan dengan Praktik Deteksi Dini Ibu Hamil Risiko Tinggi Oleh Bidan di Kabuoaten Banjarnegara Tahun 2011. [Depok]: Universitas Indonesia; 2011.

23. Widiastuti, Kartasurya, Triana, Irene M, Mawarni, Atik. Manajemen Deteksi Dini Ibu Hamil Risiko Tinggi pada Pelayanan Antenatal di Tingkat Puskesmas Kabupaten Jepara. J Manaj Kesehat Indones [Internet]. 2013;2(3). Available from: http://eprints.undip.ac.id/42966/ 